\title{
Lean manufacturing in Indian context: A survey
}

\author{
Rakesh Kumar $^{\mathrm{a}^{*}}$ and Vikas Kumar ${ }^{\mathrm{b}}$
}

${ }^{a}$ Research Scholar, Mechanical Engineering Department, YMCA University of Science and Technology, India ${ }^{b}$ Associate Professor, Mechanical Engineering Department, YMCA University of Science and Technology, India

\begin{tabular}{l}
\hline C H R O N I C L E \\
\hline Article history: \\
Received January 2, 2015 \\
Received in revised format 6 \\
February 2015 \\
Accepted 15 February 2015 \\
Available online \\
February 172015 \\
\hline Keywords: \\
Lean manufacturing \\
Lean manufacturing Elements \\
Lean manufacturing Benefits \\
Lean manufacturing obstacles \\
Drawbacks of Lean \\
manufacturing system
\end{tabular}

\section{A B S T R A C T}

This paper is an attempt to examine the implementation of Lean Manufacturing system in the Indian industries. Predominant elements of Lean Manufacturing, benefits gained after its implementation and obstacles observed by Indian Industry have been recognized. The results of this survey support the opinion that Lean Manufacturing had potential to improve the organizational performance of Indian industries. Nevertheless, Indian industries are required to be passionate to transform their manufacturing by adopting Lean manufacturing to gain the full benefits. A large numbers of literature papers are available on the better side of Lean manufacturing approach and its benefits gained by manufacturing organizations after implementation. But the adverse impacts of Lean manufacturing are not discussed to a great extent. Some drawbacks of Lean manufacturing are also highlighted in this paper.

(c) 2015 Growing Science Ltd. All rights reserved.

\section{Introduction}

Lean Manufacturing has become a subject of the attention for many manufacturing organizations. Manufacturing organizations are facing global competition by means of changing customer requirements, smaller order size with model mix, shorter product life cycles and fast delivery requirements put forward by global customers (Womack et al., 2004). Lean Manufacturing is an important management subject, which emphasis on reducing waste in the process, working with lower inventories, avoiding unnecessary investment and strengthening the overall business by reducing of non-value adding activities (Nordin et al., 2010). Lean Manufacturing has the ability to reduce the manufacturing lead time, trim down manufacturing costs, reduce material handling and get better quality. It also creates a region of reduced wastage, and shortened delivery time with lower product costs with enhanced customer satisfaction and supports other improvements, which can help companies meet competitive goals (Deif, 2012; Taj \& Morosan, 2011). The intention of Lean Manufacturing is to help organization provide the highest values to customers (Shah \& Ward 2007).

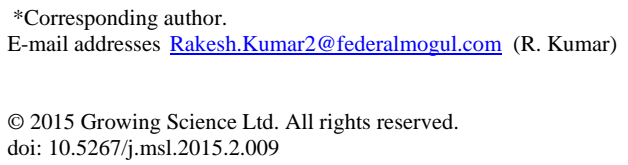


Lean Manufacturing is well accepted approach, which has gained the admired position among industry based on measurable benefits accomplished and published by practicing manufacturing organizations (Chan, 2001). Lean Manufacturing can be effectively implemented across several disciplines (Poppendieck, 2002). Lean manufacturing may be defined as a manufacturing philosophy, which focuses on delivering the highest quality product to customer on-time and at the lowest cost (Liker \& $\mathrm{Wu}, 2006)$. The essential transformation in manufacturing can be achieved and sustained with the retention and utilization of people's knowledge within the organizations. Positive changes with Lean Manufacturing Systems can be continued with a de-centralized knowledge and role-specific approach. This approach can be useful in identifying suitable procedure of knowledge management. Researchers presented management of knowledge as a matter of prime significance in Lean Manufacturing environment (Dombrowski et al., 2012).

Lean Manufacturing has been into practice for more than three decades but, still there is no established definition agreed by everybody. Lean manufacturing is directly associated with the elimination of wastes from manufacturing system to get better results in supplies, process time reduction and quality improvement (Oehmen et al., 2012). Plant not implementing lean manufacturing is likely to face performance issues in contrast with plants who have adopted Lean manufacturing in spite of age and size of the plant (Shah \& Ward, 2003).

\section{Literature review in Indian Context}

India is emerging as a manufacturing hub for the world manufacturing market. This has increased the global competition within Indian manufacturing marketplace (Kumar \& Kumar, 2012). The orthodox manufacturing approach of making product available for customer has been replaced by new manufacturing style of meeting the customer specific requirements. Indian manufacturers have started adopting modern manufacturing practices, information technologies and management approaches to meet the requirements of global competition (Antony \& Desai 2009). Though a large number of services and manufacturing industries across the country have adopted Lean manufacturing as a tool to improve their organizational performance but still there is a large gap exists in its implementation to gain the full benefits of Lean manufacturing (Narain et al., 2004).

Lean Manufacturing is a strategy adopted to achieve manufacturing excellence with continuous process improvement (Saraswat et al., 2014). Lean Manufacturing got invented in Japan with prime objective to remove waste from manufacturing processes, to improve productivity and quality of product to survive in the competitive market (Chowdary \& George 2011). Relevance of Lean Manufacturing implementation was examined in the clothing industry. The outcome revealed that Lean Manufacturing is highly effective in mass production environment of clothing industries in order to achieve superior results by waste reduction, inventory reduction and decrease of defects. Different tools of Lean Manufacturing facilitate to see the built-up waste in the system. In addition to identification of waste, it provides guideline to reduce the same (Silva, 2012).

In the start Lean Manufacturing was invented and exercised by Toyota in the Japan and later it was practiced by different companies looking for manufacturing process improvement to achieve better results by adopting latest techniques ( Ferdousi, 2009; Amasaka, 2002). These practicing companies published superior results after adoption of lean Manufacturing and this motivated other companies to adopt Lean Manufacturing to make their processes more efficient (Singh et al., 2010c). Researchers described Lean Manufacturing as a systematic way of waste removal from processes with the help of total employee's involvement within the business (Singh \& Dubey, 2013). Researchers described lean manufacturing as a prominent manufacturing approach to survive in extremely competitive environment (Mishra \& Garg, 2013). A case study in Indian industry discovered that Lean Manufacturing is the advantageous approach for the stakeholders of the organization (Anand \& Kodali, 
2008). Researchers revealed that WIP inventory reduction with the implementation of lean manufacturing can keep organizational competitiveness in recessionary times (Singh et al., 2009).

Manufacturing sector is the backbone for growth of economy for any country. With the globalization of manufacturing sector and Indian industries being a major player in global competition it is imperative for Indian industry to improve its competitiveness (Ahuja \& Khamba, 2008). It is pragmatic that Indian industry is trying to equip them with the latest tools and techniques to wrestle with global players and due to this scope of Lean manufacturing implementation is becoming broader in the Indian context. These circumstances have motivated Indian industry to adopt revolutionary approach of Lean Manufacturing (Singh et al., 2010). Customer demands are becoming more volatile and customer's expectations are increasing globally and this has increased the challenge of survival into competitive market (Khadse et al., 2013). Japanese companies have developed Lean Manufacturing as a system, which uses lesser resources to create equivalent output with better quality and meets the requirements of customer (Kumar, 2010). Continuous improvement and people participation are some of the best manufacturing practices adopted by Indian industries to up keep their competitiveness (Kumar et al., 2004).

It is observed that organizational performance is improved with the implementation of Lean Manufacturing so lean is considered as a tool to support business objectives (Joshi \& Naik, 2012). Business excellence practice are superimpose over conventional manufacturing style to create big improvements in organization (Wong et al., 2009). This transformation process starts when management alters its thought process from orthodox to contemporary. The emphasis is given on education and training of employees, allotment of funds for improvement activities, balanced resources deployment and so on. Although Lean manufacturing like any other system faces many obstacles so management should take well care of for these hindrance for smooth implementation of Lean manufacturing. Major obstacles observed by Indian industries are technical skills, cultural issues, managerial and financials to hinder the implementation of Lean manufacturing (Darabi et al., 2012). Top management issues are identified as major challenges for lean implementation along with top management policies and attitude towards lean implementation in Indian industries (Singh et al. 2010). Researchers have identified some key obstacles of Lean Manufacturing in Indian industries. The prominent barrier of Lean manufacturing is observed as management with lack of focus, being short in providing support, not able to create sense of urgency for lean manufacturing and with short sightedness about potential long tern benefits of Lean Manufacturing. Inadequate consultancy, lack of funds and communication barriers are other obstacles of Lean Manufacturing (Rakesh \& Vikas, 2014). The management is responsible for creating a learning culture and find solutions to reduce conflicts between Lean manufacturing and other improvement initiatives for smooth implementation of Lean implementation.

\section{Survey of Lean Manufacturing in Indian industries}

The process of research consists of series of steps or actions required to perform effective investigation of facts. This study is based on a survey. A survey questionnaire was designed for collecting opinion of industries professionals to collect data on Lean elements, benefits and obstacles. Research methodology model is shown in Fig. 1. Data was collected through one to one survey, emails and posts. In this study, the status of elements, benefits and obstacles have been observed. Adverse impact of lean manufacturing implementation has also been discussed. The list of Lean and continuous improvements practicing companies was obtained from confederation of Indian industry. In this study 131 industries were selected for conducting the survey. A total 59 nos. of Indian industries responded to survey including answering to mails and allowing for one to one survey. 


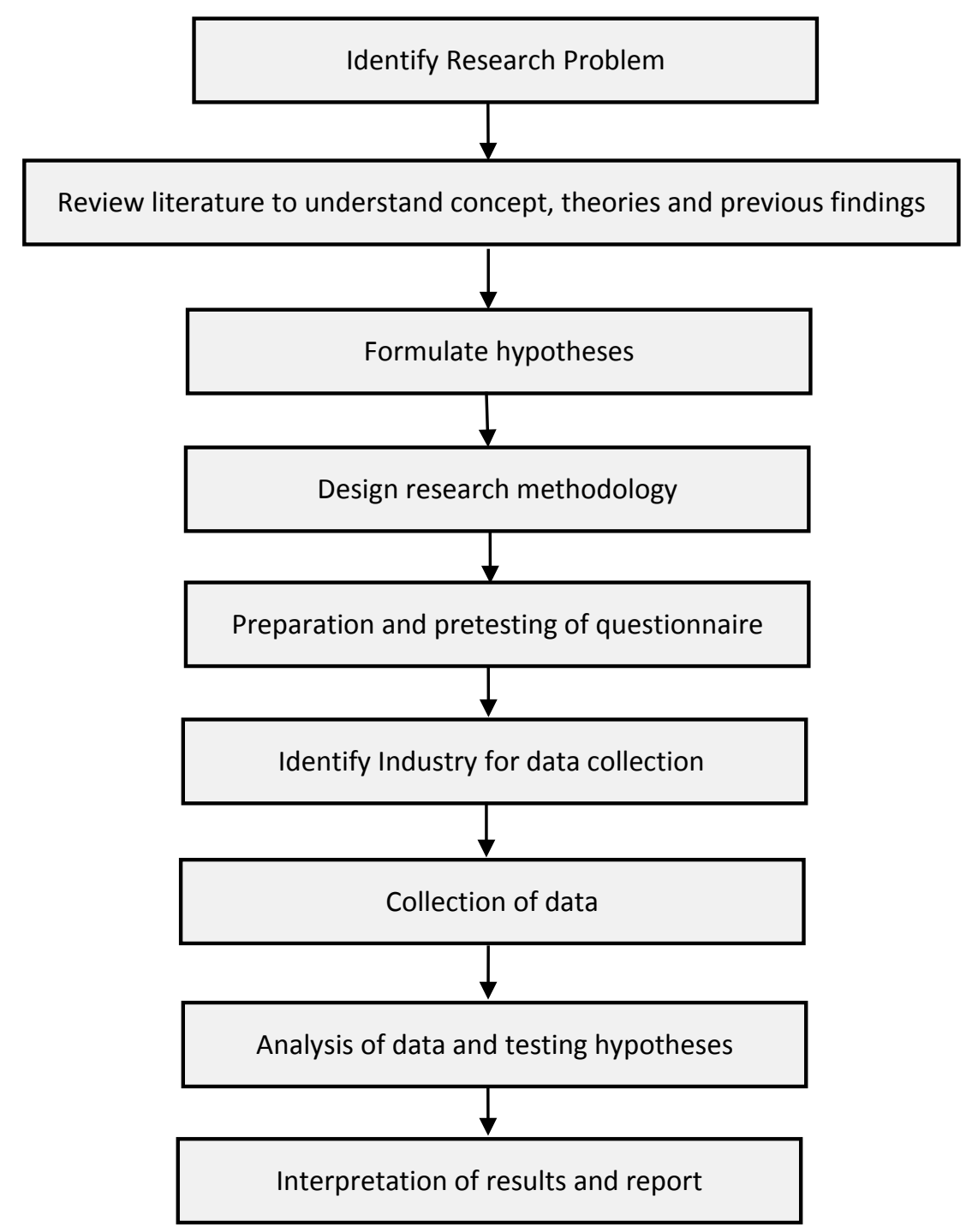

Fig. 1. Illustration of research methodology adopted for study

The respondent industries belong to two-wheeler manufacturing, four-wheeler manufacturing, passenger car manufacturing, automotive engine parts, automotive power transmission parts, rubber parts manufacturing, pharmaceutical, farm equipment manufacturing, refrigerator and air conditioner manufacturing industry and consumer goods manufacturing units. The aim of the study is to determine the subsistence of Lean manufacturing practices in Indian Industry with below objectives:

I. To establish significance of Lean Manufacturing elements related to Indian manufacturing industry.

II. To search out the benefits gained by Indian Industry with the implementation of Lean Manufacturing.

III. To identify significance of major obstacles faced by Indian Industry.

IV. To identify the adverse impact of Lean Manufacturing implementation in Indian industry.

In this study a five point Likert scale has been used to examine the degree of significance of various Lean elements, benefits and obstacles in the Indian manufacturing industries ranging from 1 as low level of significance to 5 as high level of significance. Mechanism of rating is: 1 for no significance, 2 for slight significance, and 3 for some significance, 4 for partial significance and 5 for full significance of constituent in lean manufacturing. 
Lean Manufacturing elements, benefits and obstacles have been discussed by many researchers (Singh et al., 2009; Upadhye et al., 2010; Rahman et al., 2010; Chen \& Cox, 2012; Belokar et al., 2012; Nordin et al., 2010; Kumar et al., 2004; Anand \& Kodali, 2009; Chen \& Tan, 2011; Shah \& Ward, 2003; Nordin et al., 2010; Rakesh \& Vikas, 2014; Wong \& Wong, 2011a). A total of 29 nos. of Lean manufacturing elements, 30 nos. of lean manufacturing benefits and 25 nos. of lean manufacturing obstacles have been considered for study from literature contributed by these researchers. For data collection about adverse impacts of lean manufacturing, respondents were asked to provide open ended comments based on their experiences.

\section{Analysis}

The two tailed t-test has been carried out at five percent level of significance to examine Lean manufacturing elements, benefits gained and obstacles faced by Indian industry throughout implementation of Lean manufacturing. The following hypothesis was developed.

I. $\mathrm{H}_{0}$ : Lean manufacturing elements given in Table 1 are not significant for implementation of Lean manufacturing in Indian industry. If Lean elements under analysis are significant for implementation of Lean manufacturing in Indian industry, the null hypothesis $\left(\mathrm{H}_{0}\right)$ will be rejected and alternate hypothesis $\mathrm{H}_{\mathrm{a} 1}$ will be accepted.

II. $\quad \mathrm{H}_{0}$ : Lean manufacturing benefits provided in Table 2 are not achieved by Indian industry. If benefits are gained by industry after implementation of Lean manufacturing, the null hypothesis $\left(\mathrm{H}_{0}\right)$ will be rejected and alternate hypothesis $\mathrm{H}_{\mathrm{a} 2}$ will be accepted.

III. Ho: Lean manufacturing obstacles given in Table 3 are faced by Indian industry during implementation of Lean Manufacturing. If the obstacles faced by industry during and after implementation of Lean manufacturing are not significant the null hypothesis $\left(\mathrm{H}_{0}\right)$ will be rejected and alternate hypothesis $\mathrm{H}_{\mathrm{a} 3}$ will be accepted.

\section{Table 1}

Significance of Lean manufacturing elements in Indian industry

\begin{tabular}{|c|c|c|c|c|c|c|c|c|c|c|c|}
\hline S. No. & $\begin{array}{l}\text { Lean Manufacturing } \\
\text { elements }\end{array}$ & 1 & 2 & 3 & 4 & 5 & & Std. dev. & $\mathrm{t}$ value calculated & Result & S. No. \\
\hline 1 & Inventory reduction & 0 & 1 & 13 & 23 & 22 & 4.119 & 0.811 & 2.0807 & $\mathrm{H}_{\mathrm{o}}$ rejected & $\mathrm{H}_{\mathrm{a} 1}$ accepted \\
\hline 2 & Total Employee Involvement. & 0 & 1 & 12 & 26 & 20 & 4.102 & 0.781 & 1.9943 & $\mathrm{H}_{0}$ rejected & $\mathrm{H}_{\mathrm{a} 1}$ accepted \\
\hline 3 & Error proofing/poka-Yoke & 1 & 8 & 20 & 26 & 4 & 3.407 & 0.873 & -4.3282 & $\mathrm{H}_{0}$ accepted & \\
\hline 4 & Set up reduction. & 0 & 3 & 15 & 25 & 16 & 3.915 & 0.857 & 0.1467 & $\mathrm{H}_{\mathrm{o}}$ accepted & \\
\hline 5 & Improve OEE. & 0 & 4 & 13 & 31 & 11 & 3.831 & 0.813 & -0.6463 & $\mathrm{H}_{\mathrm{o}}$ accepted & \\
\hline 6 & De-bottlenecking & 0 & 1 & 11 & 35 & 12 & 3.983 & 0.682 & 0.9478 & $\mathrm{H}_{0}$ accepted & \\
\hline 7 & Line pace & 2 & 15 & 27 & 15 & 0 & 2.932 & 0.807 & -9.2064 & $\mathrm{H}_{\mathrm{o}}$ accepted & \\
\hline 8 & Wastage identification & 0 & 1 & 14 & 20 & 24 & 4.136 & 0.840 & 2.1647 & $\mathrm{H}_{\mathrm{o}}$ rejected & $\mathrm{H}_{\mathrm{a} 1}$ accepted \\
\hline 9 & Equipment uptime & 1 & 20 & 27 & 11 & 0 & 2.814 & 0.754 & -11.0606 & $\mathrm{H}_{\mathrm{o}}$ accepted & \\
\hline 10 & Quality at source. & 0 & 2 & 7 & 38 & 12 & 4.017 & 0.682 & 1.3295 & $\mathrm{H}_{\mathrm{o}}$ accepted & \\
\hline 11 & Takt Time working & 2 & 6 & 11 & 30 & 10 & 3.678 & 0.990 & -1.7136 & $\mathrm{H}_{\mathrm{o}}$ accepted & \\
\hline 12 & Small lot size & 0 & 0 & 9 & 31 & 19 & 4.169 & 0.673 & 3.0864 & $\mathrm{H}_{0}$ rejected & $\mathrm{H}_{\mathrm{a} 1}$ accepted \\
\hline 13 & Continuous improvement & 0 & 1 & 9 & 29 & 20 & 4.153 & 0.738 & 2.6385 & $\mathrm{H}_{0}$ rejected & $\mathrm{H}_{\mathrm{a} 1}$ accepted \\
\hline 14 & Good Housekeeping & 0 & 3 & 13 & 30 & 13 & 3.898 & 0.803 & -0.0056 & $\mathrm{H}_{\mathrm{o}}$ accepted & \\
\hline 15 & Manpower reduction & 0 & 1 & 9 & 37 & 12 & 4.017 & 0.656 & 1.3817 & $\mathrm{H}_{\mathrm{o}}$ accepted & \\
\hline 16 & Load leveling (Heijunka) & 0 & 2 & 7 & 33 & 17 & 4.102 & 0.736 & 2.1175 & $\mathrm{H}_{\mathrm{o}}$ rejected & $\mathrm{H}_{\mathrm{a} 1}$ accepted \\
\hline 17 & Reduced information barriers & 0 & 11 & 10 & 24 & 14 & 3.695 & 1.038 & -1.5092 & $\mathrm{H}_{\mathrm{o}}$ accepted & \\
\hline 18 & Cycle time reduction & 0 & 3 & 5 & 34 & 17 & 4.102 & 0.759 & 2.0531 & $\mathrm{H}_{\mathrm{o}}$ rejected & $\mathrm{H}_{\mathrm{a} 1}$ accepted \\
\hline 19 & Quick changeovers & 0 & 3 & 10 & 27 & 19 & 4.051 & 0.839 & 1.3909 & $\mathrm{H}_{\mathrm{o}}$ accepted & \\
\hline 20 & Process control. & 0 & 4 & 9 & 34 & 12 & 3.915 & 0.794 & 0.1583 & $\mathrm{H}_{\mathrm{o}}$ accepted & \\
\hline 21 & Lead time reduction & 0 & 0 & 13 & 28 & 18 & 4.085 & 0.726 & 1.9662 & $\mathrm{H}_{\mathrm{o}}$ rejected & $\mathrm{H}_{\mathrm{a} 1}$ accepted \\
\hline 22 & Safe working & 0 & 2 & 12 & 28 & 17 & 4.017 & 0.799 & 1.1356 & $\mathrm{H}_{\mathrm{o}}$ accepted & \\
\hline 23 & Standardization. & 0 & 0 & 10 & 33 & 16 & 4.102 & 0.662 & 2.3545 & $\mathrm{H}_{0}$ rejected & $\mathrm{H}_{\mathrm{a} 1}$ accepted \\
\hline 24 & Reduce variability. & 0 & 5 & 13 & 27 & 14 & 3.847 & 0.887 & -0.4454 & $\mathrm{H}_{\mathrm{o}}$ accepted & \\
\hline 25 & JIT deliveries & 0 & 1 & 10 & 32 & 16 & 4.068 & 0.716 & 1.8122 & $\mathrm{H}_{\mathrm{o}}$ accepted & \\
\hline 26 & Flexible manufacturing. & 0 & 0 & 11 & 33 & 15 & 4.068 & 0.666 & 1.9480 & $\mathrm{H}_{\mathrm{o}}$ accepted & \\
\hline 27 & Layout improvement. & 2 & 4 & 10 & 34 & 9 & 3.746 & 0.921 & -1.2772 & $\mathrm{H}_{\mathrm{o}}$ accepted & \\
\hline 28 & Line Balancing & 0 & 4 & 10 & 28 & 17 & 3.983 & 0.861 & 0.7509 & $\mathrm{H}_{\mathrm{o}}$ accepted & \\
\hline 29 & Pull System & 0 & 2 & 14 & 18 & 25 & 4.119 & 0.892 & 1.8919 & $\mathrm{H}_{0}$ accepted & \\
\hline
\end{tabular}


Table 2

Benefits gained by Indian industry after implementation of Lean manufacturing

\begin{tabular}{|c|c|c|c|c|c|c|c|c|c|c|c|}
\hline $\begin{array}{c}\text { S. } \\
\text { No. }\end{array}$ & Lean Manufacturing Benefit & 1 & 2 & 3 & 4 & 5 & Element Mean & Mean & $\mathrm{t}$ value calculated & \multicolumn{2}{|c|}{ Result } \\
\hline 1 & Increase in productivity & 0 & 1 & 7 & 27 & 24 & 4.254 & 0.733 & 2.3252 & $\mathrm{H}_{\mathrm{o}}$ rejected & $\mathrm{H}_{\mathrm{a} 2}$ accepted \\
\hline 2 & Reduction in unplanned breakdown & 1 & 2 & 7 & 18 & 31 & 4.288 & 0.929 & 2.1147 & $\mathrm{H}_{\mathrm{o}}$ rejected & $\mathrm{H}_{\mathrm{a} 2}$ accepted \\
\hline 3 & Improvement in OEE & 0 & 2 & 12 & 24 & 21 & 4.085 & 0.836 & 0.4820 & $\mathrm{H}_{\mathrm{o}}$ accepted & \\
\hline 4 & Reduced rework & 2 & 4 & 11 & 25 & 17 & 3.864 & 1.025 & -1.2581 & $\mathrm{H}_{0}$ accepted & \\
\hline 5 & Reduced scrap & 1 & 2 & 4 & 26 & 26 & 4.254 & 0.863 & 1.9760 & $\mathrm{H}_{\mathrm{o}}$ rejected & $\mathrm{H}_{\mathrm{a} 2}$ accepted \\
\hline 6 & Reduced cost of poor quality & 0 & 0 & 15 & 25 & 19 & 4.068 & 0.763 & 0.3580 & $\mathrm{H}_{\mathrm{o}}$ accepted & \\
\hline 7 & Reduced warranty cost & 2 & 2 & 20 & 19 & 16 & 3.763 & 1.006 & -2.0584 & $\mathrm{H}_{0}$ accepted & \\
\hline 8 & Reduction in labor cost & 0 & 1 & 9 & 24 & 25 & 4.237 & 0.773 & 2.0367 & $\mathrm{H}_{\mathrm{o}}$ rejected & $\mathrm{H}_{\mathrm{a} 2}$ accepted \\
\hline 9 & Reduction in distribution expenses & 0 & 1 & 14 & 33 & 11 & 3.915 & 0.702 & -1.2804 & $\mathrm{H}_{\mathrm{o}}$ accepted & \\
\hline 10 & Reduction in inventory cost & 0 & 1 & 9 & 24 & 25 & 4.237 & 0.773 & 2.0367 & $\mathrm{H}_{\mathrm{o}}$ rejected & $\mathrm{H}_{\mathrm{a} 2}$ accepted \\
\hline 11 & Reduction in utility cost & 2 & 2 & 12 & 26 & 17 & 3.915 & 0.970 & -0.9265 & $\mathrm{H}_{0}$ accepted & \\
\hline 12 & Raw material yield improvement & 0 & 0 & 19 & 22 & 18 & 3.983 & 0.799 & -0.4733 & $\mathrm{H}_{\mathrm{o}}$ accepted & \\
\hline 13 & Reduction in tooling cost & 0 & 3 & 13 & 27 & 16 & 3.949 & 0.839 & -0.7607 & $\mathrm{H}_{0}$ accepted & \\
\hline 14 & Improved delivery rating of supplier & 0 & 1 & 12 & 27 & 19 & 4.085 & 0.772 & 0.5222 & $\mathrm{H}_{\mathrm{o}}$ accepted & \\
\hline 15 & Improved delivery rating to customer & 0 & 2 & 8 & 22 & 27 & 4.254 & 0.822 & 2.0744 & $\mathrm{H}_{\mathrm{o}}$ rejected & $\mathrm{H}_{\mathrm{a} 2}$ accepted \\
\hline 16 & Reduced throughput time & 1 & 2 & 4 & 24 & 28 & 4.288 & 0.872 & 2.2540 & $\mathrm{H}_{\mathrm{o}}$ rejected & $\mathrm{H}_{\mathrm{a} 2}$ accepted \\
\hline 17 & Improved flexibility & 0 & 1 & 10 & 22 & 26 & 4.237 & 0.795 & 1.9804 & $\mathrm{H}_{\mathrm{o}}$ rejected & $\mathrm{H}_{\mathrm{a} 2}$ accepted \\
\hline 18 & Reduced reportable accidents & 1 & 6 & 25 & 27 & 0 & 3.322 & 0.730 & -7.4763 & $\mathrm{H}_{\mathrm{o}}$ accepted & \\
\hline 19 & Reduced unsafe practices & 1 & 2 & 10 & 25 & 21 & 4.068 & 0.907 & 0.3009 & $\mathrm{H}_{\mathrm{o}}$ accepted & \\
\hline 20 & Improved behavioral safety & 1 & 1 & 5 & 34 & 18 & 4.136 & 0.776 & 1.0230 & $\mathrm{H}_{\mathrm{o}}$ accepted & \\
\hline 21 & Reduced environmental impact & 0 & 6 & 31 & 19 & 3 & 3.322 & 0.730 & -7.4763 & $\mathrm{H}_{\mathrm{o}}$ accepted & \\
\hline 22 & Improved legal compliance & 0 & 7 & 27 & 23 & 2 & 3.339 & 0.734 & -7.2582 & $\mathrm{H}_{\mathrm{o}}$ accepted & \\
\hline 23 & Improved skills of employee & 0 & 1 & 11 & 26 & 21 & 4.136 & 0.776 & 1.0230 & $\mathrm{H}_{\mathrm{o}}$ accepted & \\
\hline 24 & Increase in no. of Kaizens per head & 1 & 0 & 9 & 22 & 27 & 4.254 & 0.843 & 2.0404 & $\mathrm{H}_{\mathrm{o}}$ rejected & $\mathrm{H}_{\mathrm{a} 2}$ accepted \\
\hline 25 & Employees participation in trainings & 0 & 1 & 9 & 23 & 26 & 4.254 & 0.779 & 2.2259 & $\mathrm{H}_{0}$ rejected & $\mathrm{H}_{\mathrm{a} 2}$ accepted \\
\hline 26 & Employees participating in quality circles & 0 & 0 & 11 & 24 & 24 & 4.220 & 0.744 & 1.9896 & $\mathrm{H}_{\mathrm{o}}$ rejected & $\mathrm{H}_{\mathrm{a} 2}$ accepted \\
\hline 27 & Reduced attrition rate & 1 & 2 & 10 & 25 & 21 & 4.068 & 0.907 & 0.3110 & $\mathrm{H}_{\mathrm{o}}$ accepted & \\
\hline 28 & Increase in profitability & 0 & 1 & 10 & 21 & 27 & 4.254 & 0.801 & 2.2178 & $\mathrm{H}_{\mathrm{o}}$ rejected & $\mathrm{H}_{\mathrm{a} 2}$ accepted \\
\hline 29 & Increase in overall revenue & 0 & 0 & 19 & 31 & 9 & 3.831 & 0.673 & -2.4338 & $\mathrm{H}_{\mathrm{o}}$ accepted & \\
\hline 30 & Improved cash flow & 0 & 1 & 14 & 29 & 15 & 3.983 & 0.754 & -0.5341 & $\mathrm{H}_{\mathrm{o}}$ accepted & \\
\hline
\end{tabular}

Table 3

Obstacles faced by Indian industry during implementation of Lean manufacturing

\begin{tabular}{|c|c|c|c|c|c|c|c|c|c|c|c|}
\hline S. No. & Lean Manufacturing Benefit & 1 & 2 & 3 & 4 & 5 & Element Mean & Mean & $\mathrm{t}$ value calculated & Result & S. No. \\
\hline 1 & Lack of management focus & 1 & 4 & 13 & 20 & 21 & 3.949 & 1.007 & 2.1559 & $\mathrm{H}_{\mathrm{o}}$ accepted & \\
\hline 2 & Lack of urge to create sense of urgency & 0 & 8 & 19 & 19 & 13 & 3.627 & 0.981 & -0.3079 & $\mathrm{H}_{\mathrm{o}}$ rejected & $\mathrm{H}_{\mathrm{a} 3}$ accepted \\
\hline 3 & Lack of management support & 1 & 3 & 16 & 18 & 21 & 3.932 & 0.998 & 2.0462 & $\mathrm{H}_{\mathrm{o}}$ accepted & \\
\hline 4 & Lack of long term vision & 1 & 6 & 16 & 17 & 19 & 3.797 & 1.063 & 0.9404 & $\mathrm{H}_{0}$ rejected & $\mathrm{H}_{\mathrm{a} 3}$ accepted \\
\hline 5 & Lack of labor resources & 0 & 4 & 20 & 20 & 15 & 3.780 & 0.911 & 0.9546 & $\mathrm{H}_{\mathrm{o}}$ rejected & $\mathrm{H}_{\mathrm{a} 3}$ accepted \\
\hline 6 & Lack of capital fund & 0 & 3 & 17 & 22 & 17 & 3.898 & 0.885 & 2.0132 & $\mathrm{H}_{\mathrm{o}}$ accepted & \\
\hline 7 & Lack of communication & 0 & 7 & 23 & 16 & 13 & 3.593 & 0.967 & -0.5816 & $\mathrm{H}_{\mathrm{o}}$ rejected & $\mathrm{H}_{\mathrm{a} 3}$ accepted \\
\hline 8 & Lack of idea innovation & 1 & 4 & 20 & 24 & 10 & 3.644 & 0.905 & -0.1898 & $\mathrm{H}_{\mathrm{o}}$ rejected & $\mathrm{H}_{\mathrm{a} 3}$ accepted \\
\hline 9 & Mediocre Consultants & 1 & 5 & 15 & 28 & 10 & 3.695 & 0.915 & 0.2392 & $\mathrm{H}_{0}$ rejected & $\mathrm{H}_{\mathrm{a} 3}$ accepted \\
\hline 10 & Lack of time & 0 & 2 & 26 & 19 & 12 & 3.695 & 0.836 & 0.2617 & $\mathrm{H}_{\mathrm{o}}$ rejected & $\mathrm{H}_{\mathrm{a} 3}$ accepted \\
\hline 11 & Lack of training & 1 & 1 & 18 & 20 & 19 & 3.932 & 0.926 & 2.2046 & $\mathrm{H}_{0}$ accepted & \\
\hline 12 & Lack of understanding about Lean & 0 & 4 & 18 & 27 & 10 & 3.729 & 0.827 & 0.5794 & $\mathrm{H}_{\mathrm{o}}$ rejected & $\mathrm{H}_{\mathrm{a} 3}$ accepted \\
\hline 13 & Lack of implementation know-how & 0 & 5 & 15 & 19 & 20 & 3.915 & 0.970 & 1.9702 & $\mathrm{H}_{\mathrm{o}}$ accepted & \\
\hline 14 & $\begin{array}{l}\text { Conflicts with Other Initiatives like } \\
\text { TQP,TPM,JIT }\end{array}$ & 0 & 6 & 23 & 24 & 6 & 3.508 & 0.817 & -1.4845 & $\mathrm{H}_{\mathrm{o}}$ rejected & $\mathrm{H}_{\mathrm{a} 3}$ accepted \\
\hline 15 & Disparate Manufacturing Environments & 1 & 4 & 17 & 12 & 25 & 3.949 & 1.074 & 2.0227 & $\mathrm{H}_{\mathrm{o}}$ accepted & \\
\hline 16 & Demand Volatility & 2 & 3 & 22 & 20 & 12 & 3.627 & 0.981 & -0.3079 & $\mathrm{H}_{\mathrm{o}}$ rejected & $\mathrm{H}_{\mathrm{a} 3}$ accepted \\
\hline 17 & Conflicts with ERP Implementations & 1 & 3 & 15 & 26 & 14 & 3.831 & 0.913 & 1.3809 & $\mathrm{H}_{\mathrm{o}}$ rejected & $\mathrm{H}_{\mathrm{a} 3}$ accepted \\
\hline 18 & Company culture & 1 & 3 & 17 & 16 & 22 & 3.932 & 1.015 & 2.0116 & $\mathrm{H}_{\mathrm{o}}$ accepted & \\
\hline 19 & Employee resist to change & 1 & 9 & 24 & 20 & 5 & 3.322 & 0.899 & -2.9425 & $\mathrm{H}_{\circ}$ rejected & $\mathrm{H}_{\mathrm{a} 3}$ accepted \\
\hline 20 & Middle management resistance & 1 & 11 & 18 & 20 & 9 & 3.424 & 1.021 & -1.8268 & $\mathrm{H}_{\mathrm{o}}$ rejected & $\mathrm{H}_{\mathrm{a} 3}$ accepted \\
\hline 21 & No direct financial advantage & 1 & 14 & 25 & 7 & 12 & 3.254 & 1.092 & -2.8990 & $\mathrm{H}_{0}$ rejected & $\mathrm{H}_{\mathrm{a} 3}$ accepted \\
\hline 22 & Financial benefits not recognized & 1 & 8 & 21 & 19 & 10 & 3.492 & 0.989 & -1.3583 & $\mathrm{H}_{\mathrm{o}}$ rejected & $\mathrm{H}_{\mathrm{a} 3}$ accepted \\
\hline 23 & No financial targets & 1 & 5 & 12 & 20 & 21 & 3.932 & 1.032 & 1.9787 & $\mathrm{H}_{\mathrm{o}}$ accepted & \\
\hline 24 & Past experience of failure & 0 & 20 & 22 & 11 & 6 & 3.051 & 0.972 & -4.8625 & $\mathrm{H}_{0}$ rejected & $\mathrm{H}_{\mathrm{a} 3}$ accepted \\
\hline 25 & Lack of Staying Power & 0 & 13 & 28 & 14 & 4 & 3.153 & 0.847 & -4.6987 & $\mathrm{H}_{\mathrm{o}}$ rejected & $\mathrm{H}_{\mathrm{a} 3}$ accepted \\
\hline
\end{tabular}

The conclusion of the t-test is represented in Table 1 for lean manufacturing elements, in Table 2 for 
benefits gained by Indian industry and in Table 3 for obstacles faced by Indian industries. The scale used was one to five, one for low significance to five for full significance.

Significant lean manufacturing elements: Lean element index was observed as 3.89 in Table 1 based on level of significance. It was observed that lean elements such as Inventory reduction, Total employee's involvement, wastage identification, small lot size, continuous improvement, Heijunka, cycle time reduction, lead time reduction and standardization are identified significant elements in implementation of lean manufacturing in Indian industry based on survey results.

Significant lean manufacturing benefits: Index for lean benefits was observed as 4.029 in Table 2 based on level of significance. Significant benefits gained by Indian industry has been reduced throughput time, increase in productivity, reduction in unplanned breakdown, reduced scrap, reduction in labor cost, reduction in inventory cost, improved delivery rating to customers, improved flexibility, increase in number of Kaizens per head, employees participation in trainings, employees participation in quality circles and increase in profitability.

Significant lean manufacturing obstacles: Index for lean obstacles was observed as 3.608 in Table 3 based on level of significance Significant obstacles faced by Indian industry are lack of management focus, lack of management support, lack of capital fund, lack of training, lack of implementation knowhow, disparate manufacturing environments, company culture and no financial targets available for implementation of Lean Manufacturing.

\section{Drawbacks of Lean Manufacturing Implementations}

As discussed in this paper, organizations can achieve a lot of benefits with the implementation of Lean manufacturing. Despite a number of positive impacts, Lean manufacturing may have some possible drawbacks as a result of inadequate implementation of Lean manufacturing. There was no reference available for different adverse impacts of lean manufacturing. So, industrial professionals were asked to give their inputs about negative impacts experienced by them during practicing lean manufacturing. Collected inputs are summarized with the aim to make Indian industry aware of most significant adverse impacts of Lean manufacturing implementation. It is supposed that Indian industry would take care of following short comings of Lean Manufacturing during implementation.

I. Impact of over cost cutting: Lean manufacturing supports in enhancing profits by optimizing manufacturing processes but a part of this, saving is counterbalanced by direct and indirect additional cost incurred in implementation of Lean manufacturing approach. The majority of business managers are not aware of costing structure of manufacturing process. It leads them sightless about where to focus their efforts to reduce the cost and usually it ends up with cost cutting efforts in the wrong area. Sometimes due to insufficient knowledge lean manufacturing is viewed with narrow focus of cutting cost. Here chances increases to fail to spot the area of investment opportunities for business expansion which is the predominant sign of success for any industry.

II. Impact of exceptionally low inventories: Manufacturing with smaller lot size reduces throughput time and reduced inventory carrying cost but transportation of parts in smaller lots increases transportation cost. Lower inventories and frequent deliveries to customer may increase the risk of stock out situation in the absence of buffer stock which would have work as shock absorber in case of change in demand and any adverse situation.

III. Impact of overdependence on Lean guidelines: With the implementation of Lean Manufacturing most of the time consulting firms come into picture and emphasis on rigid 
management culture reducing or eliminating room for expressing basic creativity. Even if someone attempts to exercise brainstorm for new ideas, the cultural and organizational structure dampens down the creativity. Lean manufacturing approach has its limitations in pace of implementation mainly when it is exercised in conflicting workplace culture like limited openness to new ideas acceptance and innovative way of working are questioned. In this type of work culture; information flows with breadth not depth of knowledge. More often engineers feel stuck up in one career path with one company for the reason of their so highly specialized skill sets.

IV. Impact on physical and mental health: With limited knowledge of Lean manufacturing, critical lines for production are stretched from normal to highest pace creating unsafe work environment. Repeated and hasty working on such lines increases the risk of health hazard and creates issues related to operator safety. One of the most cited harmful effects of Lean manufacturing is the pressure of doing job in specific time which has potential of increased level of stress among workers.

V. Impact on society: Reduction of manpower is considered as the prime outcome of Lean Manufacturing. In many cases this is exercised just to achieve goals of manpower reduction and show improved productivity per manpower even though manpower cost is not big in Indian context. This may lead to compulsion of unnecessary investment on automation resulting in lower return on investment and creating unemployment to the society. Quality of employment is always a matter of debate considering stringent requirements and amount of work required for the successful implementation of Lean manufacturing.

VI. Impact on product quality: Quality decisions are to be taken on the spot. In most of the cases worker job is involved with making him responsible for in-process and product quality. Sometimes lower skill set and high production pressure results in wrong decisions over product quality hence increasing chance of higher cost of poor quality.

\section{Conclusions and Recommendations}

Stiff competition in the market has put pressure over product prices because key of gaining more business is to increase revenues through beating the competition by price and quality. Hence the key for making profits in competitive environment is to reduced product costs, optimizing profit margins and increasing share of business. This may need manufacturing capacity expansion. Additional expansion of capacity needs investment, which may have adverse effect on product cost. Consistently reduced product costs can be achieved by implementation of lean manufacturing to control manufacturing cost by elimination of waste in each area of business through people participative continuous improvement approach.

The empirical analysis is used in this study to establish the significant Lean elements, benefits and obstacles of Lean Manufacturing. This research paper presents benefits gained by Indian industry with implementation of Lean manufacturing elements. The survey supports the notation that the implementation of Lean Manufacturing has measurable positive impact on performance of Indian industry. Lean Manufacturing has the capability to impact positively with improved operational efficiency, quality and improved organizational performance. The outcome of the study concludes that Lean manufacturing is helpful in improvement of overall competitiveness of Indian industry to overcome the global competition. This study suggests that lean manufacturing is a great prospect to put into practice to improve the performance of the industry. Simultaneously it raises some concerns which are likely to happen if Lean manufacturing is not implemented and practiced in a balanced manner. To gain the full benefits of lean by Indian industries one must deal the obstacles with caution and 
drawbacks must be well thought-out throughout its execution.

\section{References}

Ahuja, I. P. S., \& Khamba, J. S. (2008). An evaluation of TPM initiatives in Indian industry for enhanced manufacturing performance. International Journal of Quality \& Reliability Management, 25(2), 147-172.

Amasaka, K. (2002). “New JIT”: A new management technology principle at Toyota. International Journal of Production Economics, 80(2), 135-144.

Anand, G., \& Kodali, R. (2009). Selection of lean manufacturing systems using the analytic network process-a case study. Journal of Manufacturing Technology Management, 20(2), 258-289.

Anand, G., \& Kodali, R. (2008). Selection of lean manufacturing systems using the PROMETHEE. Journal of modelling in management, 3(1), 40-70.

Antony, J., \& Desai, D. A. (2009). Assessing the status of Six Sigma implementation in the Indian industry: results from an exploratory empirical study. Management Research News, 32(5), 413-423.

Belokar, R. M., Kumar, V., \& Kharb, S. S. (2012). An Application of Value Stream Mapping In Automotive Industry: A Case Study. International Journal of Innovative Technology and Exploring Engineering, 1(2), 152-157.

Chan, F. T. S. (2001). Effect of kanban size on just-in-time manufacturing systems. Journal of Materials Processing Technology, 116(2), 146-160.

Chen, Z. X., \& Hua Tan, K. (2011). The perceived impact of JIT implementation on operations performance: Evidence from Chinese firms. Journal of Advances in Management Research, 8(2), 213-235.

Chowdary, B. V., \& George, D. (2011). Improvement of manufacturing operations at a pharmaceutical company: a lean manufacturing approach. Journal of Manufacturing Technology Management, 23(1), 56-75.

Deif, A. (2012). Assessing Lean Systems Using Variability Mapping. Procedia CIRP, 3, 2-7.

Dombrowski, U., Mielke, T., \& Engel, C. (2012). Knowledge management in lean production systems. Procedia CIRP, 3, 436-441.

Ferdousi, F. (2009). An investigation of manufacturing performance improvement through lean production: A study on Bangladeshi garment firms. International Journal of Business and Management, 4(9), p106.

Chen, J. C., \& Cox, R. A. (2012). Value Stream Management for Lean Office-A Case Study.

Joshi, M. R. R., \& Naik, G. R. (2012, March). Process improvement by using value stream mapping:-A case study in small scale industry. International Journal of Engineering Research and Technology, 1(5), ESRSA Publications.

Khadse, P. B., Sarode, A. D., \& Wasu, R. (2013). Lean manufacturing in Indian industries: A Review. International Journal of Latest Trends in Engineering and Technology, 3(1), 175-181.

Kumar, R., \& Kumar, V. (2012, October). Lean Manufacturing System: An overview. In Proceedings of the National Conference on Trends and Advances in Mechanical Engineering, YMCA. University of Science \& Technology, Faridabad, Haryana (pp. 742-747).

Kumar, V. (2010). JIT based quality management: concepts and implications in Indian context. International Journal of Engineering Science and Technology, 2(1), 40-50.

Liker, J. K., \& Wu, Y. C. (2006). Japanese automakers, US suppliers and supply chain superiority. Supply Chains and Total Product Systems: A Reader, 177-196.

Mishra, O., \& Garg, D. (2013). JIT supply chain; an investigation through general system theory. Management Science Letters, 3(3), 743-752.

Narain, R., Yadav, R. C., \& Antony, J. (2004). Productivity gains from flexible manufacturing: Experiences from India. International Journal of Productivity and Performance Management, 53(2), 109-128.

Nordin, N., Deros, B. M., \& Wahab, D. A. (2010). A survey on lean manufacturing implementation in Malaysian automotive industry. International Journal of Innovation, Management and Technology, 
1(4), 374-380.

Oehmen, J., Oppenheim, B. W., Secor, D., Norman, E., Rebentisch, E., Sopko, J. A., ... \& Driessnack, J. (2012). The guide to lean enablers for managing engineering programs.

Rahman, S., Laosirihongthong, T., \& Sohal, A. S. (2010). Impact of lean strategy on operational performance: a study of Thai manufacturing companies. Journal of Manufacturing Technology Management, 21(7), 839-852.

Saraswat, P., Sain, M. K., \& Kumar, D. (2014). A Review on Waste Reduction through Value Stream Mapping Analysis. International Journal of Research, 1(6), 200-207.

Shah, R., \& Ward, P. T. (2003). Lean manufacturing: context, practice bundles, and performance. Journal of Operations Management, 21(2), 129-149.

Shah, R., \& Ward, P. T. (2007). Defining and developing measures of lean production. Journal of Operations Management, 25(4), 785-805.

Silva, S. K. P. N. (2012). Applicability of Value Stream Mapping (VSM) in the Apparel industry in Sri Lanka. International Journal of Lean Thinking, 3(1), 36-41.

Singh, B., Garg, S. K., \& Sharma, S. K. (2009). Lean can be a survival strategy during recessionary times. International Journal of Productivity and Performance Management, 58(8), 803-808.

Singh, B., Garg, S. K., Sharma, S. K., \& Grewal, C. (2010). Lean implementation and its benefits to production industry. International Journal of Lean Six Sigma, 1(2), 157-168.

Singh, B., Garg, S. K., \& Sharma, S. K. (2010). Development of index for measuring leanness: study of an Indian auto component industry. Measuring Business Excellence, 14(2), 46-53.

Singh, T., \& Dubey, R. (2013). Soft TQM practices in Indian cement industry-an empirical study. International Journal of Productivity and Quality Management, 11(1), 1-28.

Taj, S., \& Morosan, C. (2011). The impact of lean operations on the Chinese manufacturing performance. Journal of Manufacturing Technology Management, 22(2), 223-240.

Upadhye, N., Deshmukh, S. G., \& Garg, S. (2010). Lean manufacturing system for medium size manufacturing enterprises: an Indian case. International Journal of Management Science and Engineering Management, 5(5), 362-375.

Kumar, V., Garg, D., \& Mehta, N. P. (2004). JIT practices in Indian context: A survey. Journal of Scientific and Industrial Research, 63(8), 655-662.

Womack, J. P., Jones, D. T., \& Roos, D. (2008). The machine that changed the world. Simon and Schuster.

Wong, Y. C., Wong, K. Y., \& Ali, A. (2009). A study on lean manufacturing implementation in the Malaysian electrical and electronics industry. European Journal of Scientific Research, 38(4), 521535.

Wong, Y. C., \& Wong, K. Y. (2011). Approaches and practices of lean manufacturing: The case of electrical and electronics companies. African Journal of Business Management, 5(6), 2164-2174.

Wong, Y. C., \& Wong, K. Y. (2011, June). A lean manufacturing framework for the Malaysian electrical and electronics industry. In 3rd International Conference on Information and Financial Engineering, IPEDR (Vol. 12, pp. 30-34). 